\title{
Coupling of methyl and total mercury in a minerotrophic peat bog in southeastern Sweden
}

\author{
O. Regnell and T. Hammar
}

\begin{abstract}
During most of an annual cycle, we studied the temporal variation of total mercury $\left(\mathrm{Hg}_{\mathrm{T}}\right)$ and methyl mercury $(\mathrm{MeHg})$ in unfiltered and filtered $(0.45 \mu \mathrm{m})$ peat water from a minerotrophic peat bog in southeastern Sweden. $\mathrm{MeHg}$ in bulk water $\left(\left[\mathrm{MeHg}_{\mathrm{T}}\right]\right)$ and total $\mathrm{Hg}$ in filtered water in discharge water from the peat bog $\left(\left[\mathrm{Hg}_{\mathrm{D}}\right]\right)$ were an order of magnitude higher than in upland runoff water entering the peat bog. At the discharge end, peat-water $\left[\mathrm{Hg}_{\mathrm{D}}\right]$ and $\left[\mathrm{MeHg}_{\mathrm{D}}\right]$ ranged from 8 to $54 \mathrm{pmol} \cdot \mathrm{L}^{-1}$ and from 1 to $32 \mathrm{pmol} \cdot \mathrm{L}^{-1}$, respectively. Whereas the variation of $\left[\mathrm{MeHg}_{\mathrm{T}}\right]$ was explained by changes in $\left[\mathrm{MeHg}_{\mathrm{D}}\right]$, the variation of inorganic $\mathrm{Hg}_{\mathrm{T}}\left[\mathrm{IHg}_{\mathrm{T}}\right]=\left[\mathrm{Hg}_{\mathrm{T}}\right]-\left[\mathrm{MeHg}_{\mathrm{T}}\right]$ was explained by changes in particle-bound $\mathrm{IHg}\left[\mathrm{IHg}_{\mathrm{P}}\right]=\left[\mathrm{IHg}_{\mathrm{T}}\right]-\left[\mathrm{IHg}_{\mathrm{D}}\right]$. Filterable organic matter and sulfide in the water both correlated poorly with $\left[\mathrm{Hg}_{\mathrm{D}}\right]$. Neither did the amount of $\mathrm{Hg}_{\mathrm{T}}$ in precipitation and upland runoff water correlate well with the estimated discharge of $\mathrm{Hg}_{\mathrm{D}}$ from the peat bog. However, there was a strong correlation between [ $\left.\mathrm{Hg}_{\mathrm{D}}\right]$ and $\left[\mathrm{MeHg}_{\mathrm{T}}\right]$ in the peat water $(r=0.96)$. Furthermore, a significant fraction of $\mathrm{Hg}_{\mathrm{D}}$ was $\mathrm{MeHg}(\operatorname{mean} 28 \%$; range $8-$ $60 \%$ ). These results suggest that methylation increased the mobility of $\mathrm{Hg}$.
\end{abstract}

Résumé : Nous avons suivi, sur presque tout un cycle annuel, la variation temporelle du mercure $\left(\mathrm{Hg}_{\mathrm{T}}\right)$ total et du méthyl-mercure dans l'eau de tourbière filtrée $(0,45 \mu \mathrm{m})$ et non filtrée, prélevée dans une tourbière minérotrophe du sudest de la Suède. Les concentrations de méthyl-mercure dans l'eau brute ( $\left.\left[\mathrm{MeHg}_{\mathrm{T}}\right]\right)$ et de mercure total dan l'eau filtrée $\left(\left[\mathrm{Hg}_{\mathrm{D}}\right]\right)$ sont de l'ordre de 10 fois plus élevées dans l'eau de drainage de la tourbière que dans l'eau de ruissellement qui coule vers la tourbière en amont. Au point de drainage, $\left[\mathrm{Hg}_{\mathrm{D}}\right]$ et $\left[\mathrm{MeHg}_{\mathrm{D}}\right]$ de l'eau de la tourbière varient respectivement de $8-54 \mathrm{pmol} \cdot \mathrm{L}^{-1}$ et de $1-32 \mathrm{pmol} \cdot \mathrm{L}^{-1}$. Alors que la variation de $\left[\mathrm{MeHg}_{\mathrm{T}}\right]$ s'explique par les changements de $\left[\mathrm{MeHg}_{\mathrm{D}}\right]$, la variation de $\left[\mathrm{IHg}_{\mathrm{T}}\right]=\left[\mathrm{Hg}_{\mathrm{T}}\right]-\left[\mathrm{MeHg}_{\mathrm{T}}\right]$ s'explique par les changements de $\left[\mathrm{IHg}_{\mathrm{P}}\right]=\left[\mathrm{IHg}_{\mathrm{T}}\right]-\left[\mathrm{IHg}_{\mathrm{D}}\right] . \mathrm{Il} \mathrm{y}$ a peu de corrélation entre la matière organique filtrable et le sulfite dans l'eau, d'une part, et $\left[\mathrm{Hg}_{\mathrm{D}}\right]$, d'autre part. Il n'y a pas non plus de bonne corrélation entre la quantité de $\mathrm{Hg}_{\mathrm{T}}$ dans les précipitations et dans l'eau de ruissellement d'amont, d'une part, et l'exportation estimée de $\mathrm{Hg}_{\mathrm{D}}$ de la tourbière, d'autre part. Il y a cependant une forte corrélation $(r=0,96)$ entre $\left[\mathrm{Hg}_{\mathrm{D}}\right]$ et $\left[\mathrm{MeHg}_{\mathrm{T}}\right]$ dans l'eau de la tourbière. De plus, une fraction significative de $\mathrm{Hg}_{\mathrm{D}}$ est en fait $\mathrm{MeHg}$ (moyenne, $28 \%$; étendue, 8-60\%). Ces résultats indiquent que la méthylation augmente la mobilité de Hg.

[Traduit par la Rédaction]

\section{Introduction}

Several studies indicate that drainage lakes and rivers can receive significant quantities of methyl mercury $(\mathrm{MeHg})$ from hydrologically connected wetlands (e.g., St. Louis et al. 1994; Hurley et al. 1995; Waldron et al. 2000). In contrast to inorganic $\mathrm{Hg}(\mathrm{IHg}), \mathrm{MeHg}$ is biomagnified in aquatic food webs, leading to bioconcentration factors ([MeHg $]_{\text {organism }} /$ $[\mathrm{MeHg}]_{\text {water }}$ ) of up to $10^{7}$ for predaceous fish (Surma-Aho et al. 1986; Driscoll et al. 1994). Highly neurotoxic $\mathrm{MeHg}$ readily passes the blood-brain barrier and the bloodplacenta barrier. Furthermore, the human fetus is known to be highly sensitive to $\mathrm{MeHg}$ exposure during development (Clarkson 1990; Choi 1991). This has prompted health authorities to issue fish-consumption advisories for a large

Received 23 July 2003. Accepted 8 July 2004. Published on the NRC Research Press Web site at http://cjfas.nrc.ca on 24 December 2004.

J17659

O. Regnell. ${ }^{1}$ Ecotoxicology, Department of Ecology, University of Lund, Sölvegatan 37, SE-223 62 Lund, Sweden. T. Hammar. Environmental Unit, Kalmar County Administration, SE-391 86 Kalmar, Sweden.

${ }^{1}$ Corresponding author (e-mail: Olof.Regnell@ecotox.lu.se). number of lakes and rivers in Canada, the USA, and Scandinavia (e.g., Sorensen et al. 1990; Johansson et al. 2001).

In wetlands, organic matter (OM) is degraded anaerobically. A large number of studies have shown that net $\mathrm{Hg}$ methylation rates are considerably higher under anaerobic than aerobic conditions (e.g., Compeau and Bartha 1984; Regnell and Tunlid 1991; Regnell et al. 1997). More specifically, there seems to be a strong link between dissimilatory sulfate reduction and $\mathrm{Hg}$ methylation (e.g., Compeau and Bartha 1985; Gilmour et al. 1992; Branfireun et al. 1999).

A relatively small fraction of the total atmospheric $\mathrm{Hg}$ deposition on boreal-forest watersheds may reach surface waters, the remainder being either volatilized or retained in the soil (Swain et al. 1992; Quemarais et al. 1999). Several studies indicate that the retention of $\mathrm{Hg}$ in wetlands is lower than in upland soils (e.g., Mierle 1990; Hurley et al. 1995; Waldron et al. 2000). This is a somewhat surprising finding, considering the fact that $\mathrm{Hg}$ interacts strongly with surface components of live and dead OM. Notably, inorganic divalent $\mathrm{Hg}(\mathrm{Hg}(\mathrm{II}))$ has a very high affinity for reduced organic sulfur (Hesterberg et al. 2001). However, several processes can remove $\mathrm{Hg}(\mathrm{II})$ from particulate organic matter and other solids and (or) counteract its tendency to sorb to solids. Such processes represent 
Fig. 1. Locations of the peat bog and the sampling sites for peat water (PW), upland runoff water entering the peat bog (UW), wet deposition (WD), and observation wells for water-level measurements (OW). The river-water samples discussed in the paper were sampled approximately $5 \mathrm{~km}$ downstream of the lakes. Depth isopleths $(\mathrm{m})$ are shown for the lakes. The inset map shows the location in Sweden.

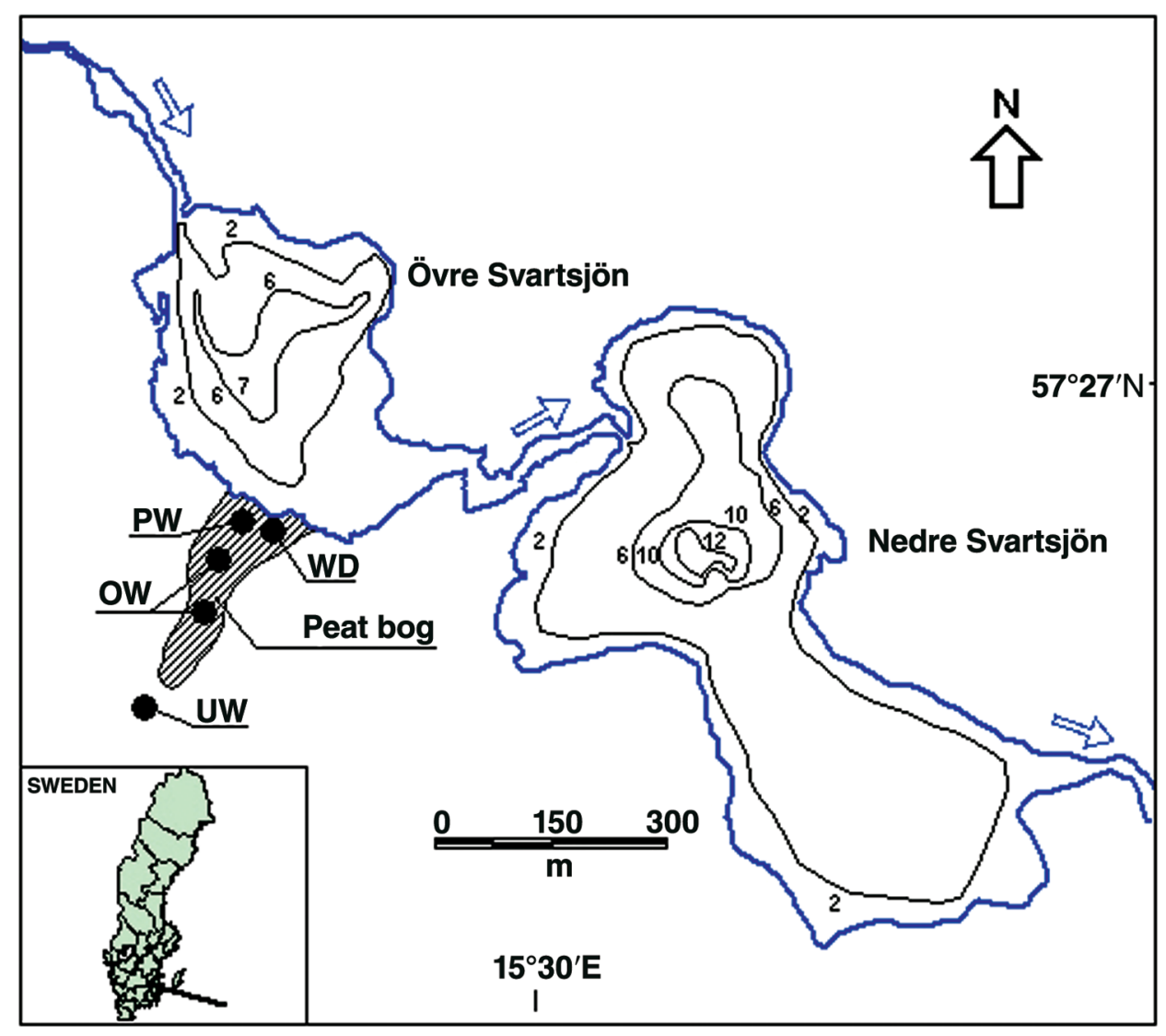

heterotrophic activity leading to degradation of particulate organic matter (Schlüter 1996; Drexel et al. 2002), complexation of $\mathrm{Hg}(\mathrm{II})$ by inorganic sulfide and dissolved organosulfur compounds (Benoit et al. 1999), and reductive dissolution of iron and manganese oxides (Regnell et al. 1997, 2001).

In comparison with $\mathrm{Hg}(\mathrm{II}), \mathrm{MeHg}$ has a somewhat lower affinity for reduced-sulfur functional groups because the methyl group withdraws electrons and decreases the covalent character of the $\mathrm{Hg}-\mathrm{S}$ bonding (Craig 1986). Furthermore, unlike $\mathrm{Hg}(\mathrm{II})$, $\mathrm{MeHg}$ rapidly exchanges reduced-sulfur ligands (Carty and Malone 1979; Jackson 1998). Hence, methylation can be expected to increase the mobility of $\mathrm{Hg}$. Recently, it was reported that $\mathrm{MeHg}$ constituted $60 \%-80 \%$ of total $\mathrm{Hg}\left(\mathrm{Hg}_{\mathrm{T}}\right)$ in water flowing out of an experimentally flooded wetland in northeastern Ontario (St. Louis et al. 2004); the authors stated that methylation probably increased the mobility of $\mathrm{Hg}$.

The present paper is based on data obtained from a minerotrophic peat bog in southeastern Sweden. Our objective was to determine relationships between the release of $\mathrm{Hg}$ and environmental conditions, to develop testable hypotheses regarding processes that affect the mobilization of $\mathrm{Hg}$ in peat bogs.

\section{Materials and methods}

\section{Study site}

The study site is a Sphagnum-dominated minerotrophic peat bog (1.3 ha) within a watershed ( 84 ha) dominated by coniferous forest in southeastern Sweden (Fig. 1). The discharge to the peat bog is mainly ground water from a valley that collects surface runoff as well as soil ground water from the surrounding hills. The valley directs these flows to the peat bog, the latter being an exfiltration area for ground water at the mouth of the valley. During most of the year, flow takes place as ground water. However, during periods of high discharge (mainly snowmelt), a surface stream occurs at the bottom of the valley and is spread over the peat bog as diffuse surface water. Hydrological investigations indicate that about $90 \%$ of the discharge from the valley takes place in the soil (including occasional surface water) and is directed through the peat bog, while the remaining part leaves the area through fracture zones in the bedrock. At the mouth of the valley, where the soil surface and moraine are overlain by peat, the ground-water level reaches the soil surface. The ground-water discharge and occasional surface runoff from the valley thus pass the peat bog before being discharged to the lake (Övre Svartsjön) (Fig. 1). Basic chemical and physical data from the peat water are given in Table 1.

It is possible that the bog has received $\mathrm{Hg}$ from a paper mill located $2.5 \mathrm{~km}$ upstream of the lakes shown, which used phenyl $\mathrm{Hg}$ as a slimicide until 1965. The lake remains a potential source of $\mathrm{Hg}$, but we found that $\left[\mathrm{Hg}_{\mathrm{T}}\right]$ in the peat water was typically several times higher than in the epilimnetic lake water. This indicated that the lake is no longer a significant source of $\mathrm{Hg}$ to the peat bog. We recently pub- 
Table 1. Basic chemical and physical characteristics of the peat water at the discharge end of the peat bog during the study period (May-December 1996).

\begin{tabular}{lcc}
\hline & Average & Range \\
\hline Temperature $\left({ }^{\circ} \mathrm{C}\right)$ & 9.3 & $1.8-18.3$ \\
Conductivity $\left(\mathrm{mS} \cdot \mathrm{m}^{-1}\right)$ & 6.6 & $5.1-7.2$ \\
$\mathrm{pH}$ & 5.7 & $5.4-6.0$ \\
Total organic $\mathrm{C}\left(\mathrm{mmol} \cdot \mathrm{L}^{-1}\right)$ & 2.1 & $1.4-2.6$ \\
Total $\mathrm{N}\left(\mathrm{mmol} \cdot \mathrm{L}^{-1}\right)$ & 0.10 & $0.06-0.14$ \\
Total $\mathrm{P}\left(\mu \mathrm{mol} \cdot \mathrm{L}^{-1}\right)$ & 2.1 & $1.1-5.2$ \\
Sulfate $\left(\mu \mathrm{mol} \cdot \mathrm{L}^{-1}\right)$ & 69 & $31-150$ \\
\hline
\end{tabular}

lished a paper about $\mathrm{Hg}$ in the sediment and water of this lake (Regnell et al. 2001).

\section{Sampling}

During May-December 1996, we sampled one site for water entering the peat bog from the valley and one site for water flowing out of the peat bog to the lake (Fig. 1). Focusing on these two sites allowed for a sufficiently high number of sampling occasions (17 times) to study the temporal relationships between different environmental variables and the levels and fluxes of $\mathrm{Hg}_{\mathrm{T}}$ and $\mathrm{MeHg}$. It also enabled us to study the ratio between $\mathrm{MeHg}$ and $\mathrm{Hg}_{\mathrm{T}}$ over most of an annual cycle. Admittedly, however, this may limit the applicability of the findings to other peat bogs because a narrower range of conditions were tested than would have been the case if more sites had been sampled. Considering the fact that surface water flow rarely occurs, it was concluded that representative samples of the water flowing into the peat bog were best obtained by sampling ground water in the moraine close to the surface. This was achieved by pumping from a permanently installed piezometer (polyethylene, $5000 \mathrm{~mm}$, inner diameter (i.d.) $50 \mathrm{~mm}$, slit width $0.2 \mathrm{~mm}$ ). On each sampling occasion, at least one volume of water was withdrawn from the piezometer before the samples were taken. Water flow through the peat bog takes place mainly in the peat layer. Sampling of this water at the lower end of the peat bog took place in the upper part of the peat $(0-90 \mathrm{~cm})$, where permeability is highest because of intermittent freezing and thawing. Yet there is probably a decrease in hydrological conductivity with depth within the sampled 0- to 90-cm layer. Hence, fluxes of elements and compounds associated with microbial activity, the latter being highest in the upper portion of the peat, may have been underestimated (e.g., the flux of $\mathrm{MeHg}$ ). Each sample was obtained by manually inserting a pointed plastic (polyethylene) cylinder with slits (length $1090 \mathrm{~mm}$, i.d. $50 \mathrm{~mm}$, slit width $0.2 \mathrm{~mm}$ ) into the live moss and peat. Filtered samples from both sites were obtained immediately in the field using acid-washed plastic syringes to which $0.45 \mu \mathrm{m}$ filters (Millex-HA, Millipore) were fitted. Long gloves were always used when water samples intended for $\mathrm{Hg}$ determinations were handled. Samples for $\mathrm{Hg}$ determination were transferred to Teflon bottles $(120 \mathrm{~mL})$. These were emptied of their content of ultraclean MQ water and $0.5 \mathrm{~mL}$ of concentrated $\mathrm{HCl}$, and washed once with sample water. The bottles were then transferred to a refrigerated box and sent to the laboratory less than $24 \mathrm{~h}$ after sampling.
Water samples were also taken at turbulent sites in the river that flows through the adjacent lake by immersing Teflon bottles by hand. The reported site was located approximately $5 \mathrm{~km}$ below the lakes shown (Fig. 1).

Two wet-deposition collectors were deployed close to the sampling site for peat water (Fig. 1). These were emptied monthly. They consisted of a funnel (i.d. $82 \mathrm{~mm}$ ) and a sampling bottle made of borosilicate glass. A capillary tube connected the funnel to the sampling bottle. The latter was shielded from light and contained $2.5 \mathrm{~mL}$ of $\mathrm{HCl}$ (Suprapur) (Iverfeldt 1991).

\section{Chemical analyses}

$\mathrm{Hg}_{\mathrm{T}}$ samples were wet-oxidized by adding $\mathrm{BrCl}$. $\mathrm{NH}_{2} \mathrm{OH} \cdot \mathrm{HCl}$ was then added prior to reduction of all $\mathrm{Hg}$ compounds to $\mathrm{Hg}^{0}$ by $\mathrm{SnCl}_{2}$. A technique involving doubleamalgamation and atomic fluorescence detection was used for quantification. $\mathrm{MeHg}$ was extracted by a distillation procedure. After aqueous-phase ethylation, separation by isothermal gas chromatography and pyrolysis, it was quantified using an atomic fluorescence detector. For the peat-water samples, artifact formation of $\mathrm{MeHg}$ during distillation could be safely neglected because of the high proportion of $\mathrm{Hg}_{\mathrm{T}}$ that was present as $\mathrm{MeHg}$. The detection limits of $\mathrm{Hg}_{\mathrm{T}}$ and $\mathrm{MeHg}_{\mathrm{T}}$ were 0.25 and $0.1 \mathrm{pmol} / \mathrm{L}$, respectively.

Sulfide was measured colorimetrically using the methylene blue method (Fonselius 1983). The samples were stabilized in the field by addition of $\mathrm{NaOH}$ and zinc acetate.

Total organic carbon (TOC) in water was determined using a carbon analyzer (Shimadzu, TOC-500). Particulate organic carbon (POC) was estimated from the concentration of suspended particulate matter (collected on $1.6 \mu \mathrm{m}$ filters) and the ignition loss $\left(550{ }^{\circ} \mathrm{C}\right)$ of the suspended particulate matter. A factor of 0.5 was used to convert ignition loss to POC. This factor was obtained from settling matter in the river that was determined with respect to both TOC and ignition loss. For these samples, the ratio was in the interval [0.42, 0.53 ] $(n=32)$. Dissolved organic carbon (DOC) was calculated as TOC - POC. Color was measured as absorbance $(420 \mathrm{~nm})$ after filtration through $0.45 \mu \mathrm{m}$ filters (Millex-HA, Millipore). This is a measure of the concentration of humic and fulvic matter that is strongly correlated with DOC (Mierle and Ingram 1991).

\section{Water-discharge measurements}

The velocity-area method was used to estimate the water discharge of the river. An electromagnetic current meter (Nautilus C 2000) measured the speed of water in different vertical sections of the river. These measurements were used to obtain an integrated average water velocity for the entire cross section.

The discharge from the valley through the peat bog was modelled with Hydrological Evaluation of Leachate Performance (HELP; version 3.05). This model is a quasi-twodimensional hydrologic model for conducting water-balance analyses of landfills, cover systems, and other solid waste containment facilities. However, the model is also applicable to natural soil profiles, using the same solution techniques as for cover systems. In the model, the soil profile of the valley was represented by two layers, the upper layer having a hydraulic conductivity of $1 \times 10^{-6} \mathrm{~m} \cdot \mathrm{s}^{-1}$ and the lower layer 
Fig. 2. Concentration of (a) filterable total $\mathrm{Hg}\left(\mathrm{Hg}_{\mathrm{D}}\right.$; except for wet deposition, for which total $\mathrm{Hg}$ in bulk water is shown) and (b) methyl $\mathrm{Hg}(\mathrm{MeHg})$ in unfiltered water during the study period in runoff water, peat water, and wet deposition. Minimum values (open bars), averages (shaded bars), and maximum values (solid bars) are shown.

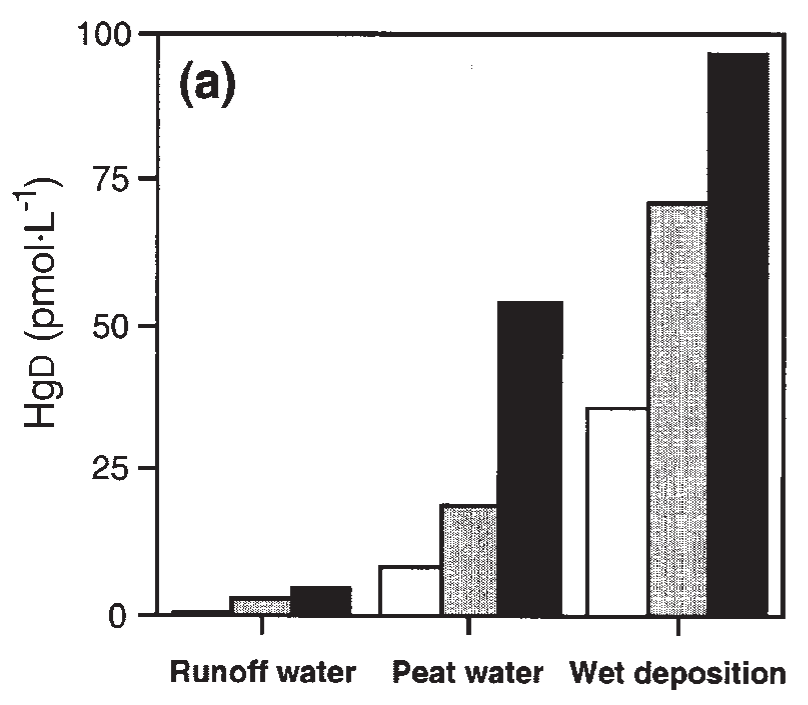

(bedrock) having a hydraulic conductivity of $1 \times 10^{-9} \mathrm{~m} \cdot \mathrm{s}^{-1}$, acting as a barrier to vertical percolation. The input of the model consisted of daily data on precipitation, temperature, and solar radiation, mean quarterly humidity, and mean wind speed, together with soil data (hydraulic conductivity, porosity, field capacity, and wilting point) and design data (the geometry of the two-dimensional soil profile, evaporative zone depth, and vegetation intensity). The model was then used to calculate evapotranspiration, surface runoff, groundwater level, lateral ground-water flow in the soil layer, and percolation to deeper ground water in the bedrock.

Calculations were performed for a series of years (19911996) to allow comparisons between calculated discharge and regional discharge reported by the Swedish Meteorological and Hydrological Institute. The model resulted in a ground-water table close to that found in the field, and a total discharge (surface runoff and ground-water formation) normalized to the area similar to the total regional discharge as measured in the rivers.

When calculating the discharge of $\mathrm{Hg}_{\mathrm{D}}\left(\mathrm{Hg}_{\mathrm{D} \text { (flux })}\right)$ and $\mathrm{MeHg}_{\mathrm{T}}\left(\mathrm{MeHg}_{\mathrm{T} \text { (flux) }}\right)$ from the peat bog, we assumed that $\left[\mathrm{Hg}_{\mathrm{D}}\right]$ and $\left[\mathrm{MeHg}_{\mathrm{T}}\right]$ measured at the lower station represented $\left[\mathrm{Hg}_{\mathrm{D}}\right]$ and $\left[\mathrm{MeHg}_{\mathrm{T}}\right]$ in the discharge water.

\section{Data analysis}

To study covariation between variables, Pearson's productmoment correlation coefficients $(r)$ were computed. Fisher's $z$ test was used to determine the associated significant probability $(P)$. The latter was corrected using a sequential Bonferroni test (Sokal and Rohlf 1995).

\section{Results and discussion}

$\mathrm{MeHg}$ and $\mathrm{Hg}_{\mathrm{T}}$ in rain, in runoff from the watershed, and in the peat water

Average $\left[\mathrm{Hg}_{\mathrm{D}}\right]$ and $\left[\mathrm{MeHg}_{\mathrm{T}}\right]$ were an order of magnitude lower in the catchment runoff water than in the peat water at

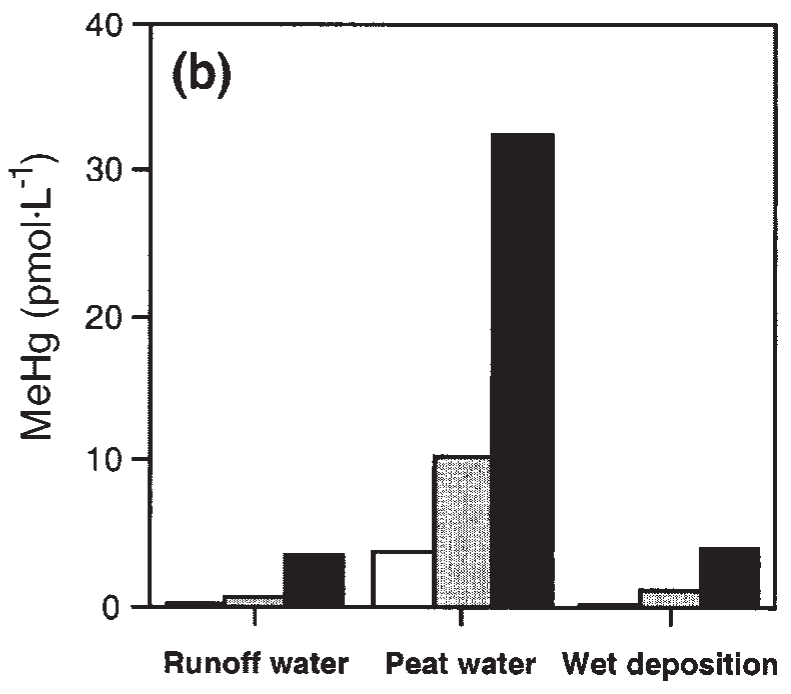

the discharge end of the peat bog. In wet deposition, $\left[\mathrm{Hg}_{\mathrm{T}}\right]$ was higher and $\left[\mathrm{MeHg}_{\mathrm{T}}\right]$ lower, the latter by an order of magnitude than $\left[\mathrm{Hg}_{\mathrm{T}}\right]$ and $\left[\mathrm{MeHg}_{\mathrm{T}}\right]$, respectively, in the peat water (Fig. 2). These results indicate that most of the MeHg in the discharge water was formed in the peat bog. Branfireun et al. (1996) reported similar results from a peatland study in Ontario. Furthermore, the fact that $\mathrm{Hg}_{\mathrm{D} \text { (flux) }}$ showed no apparent relationship with the wet deposition of $\mathrm{Hg}_{\mathrm{T}}$ (Fig. 3) indicated that the amount of $\mathrm{Hg}_{\mathrm{D}}$ that was available for export was controlled by partitioning of $\mathrm{Hg}$ between the solid phase (live moss and peat) and the water phase. We conclude that processes within the peat bog, together with water-discharge and water levels, controlled the seasonal variation of both $\left[\mathrm{MeHg}_{\mathrm{T}}\right]$ and $\left[\mathrm{Hg}_{\mathrm{D}}\right]$ in the discharge water. The underlying assumption here is that the difference in water chemistry between the upland site and the lower site was not far from the true difference in water chemistry between the water flowing into and out of the peat bog.

\section{Methylation and release of $\mathbf{H g}$ from the solid phase}

The most striking finding was a strong correlation $(r=$ $0.96, P<0.0001)$ between $\left[\mathrm{MeHg}_{\mathrm{T}}\right]$ and $\left[\mathrm{Hg}_{\mathrm{D}}\right]$ in the peat water (Fig. 4, Table 2). A comparison of temporal variation between $\left[\mathrm{MeHg}_{\mathrm{T}}\right]$ and $\left[\mathrm{Hg}_{\mathrm{D}}\right]$ strengthens the impression that these variables were strongly related (Fig. $5 a, 5 b$ ). We concluded above that $\left[\mathrm{Hg}_{\mathrm{D}}\right]$ is a function of solid/water partitioning of $\mathrm{Hg}$ in the peat bog and water discharge. Consequently, we claim that the correlation between $\left[\mathrm{MeHg}_{\mathrm{T}}\right]$ and $\left[\mathrm{Hg}_{\mathrm{D}}\right]$ illustrates a strong relationship between the $\mathrm{MeHg}$ levels in the peat water and the release of $\mathrm{Hg}$ from the solid phase. Certainly, $\left[\mathrm{MeHg}_{\mathrm{T}}\right]$ and $\left[\mathrm{Hg}_{\mathrm{D}}\right]$ have the component $\left[\mathrm{MeHg}_{\mathrm{D}}\right]$ in common. This is not a problem as long as the correlation is used to corroborate the hypothesis that methylation of $\mathrm{Hg}$ increases the probability that $\mathrm{Hg}$ partitions into water. To realize this one can consider the case $\left[\mathrm{Hg}_{\mathrm{D}}\right]=\left[\mathrm{MeHg}_{\mathrm{D}}\right]$. However, to test the hypothesis that methylation of $\mathrm{Hg}$ is controlled by release of $\mathrm{Hg}$ from the 
Fig. 3. Temporal variation of atmospheric wet deposition of $\mathrm{Hg}_{\mathrm{T}}$ on the peat bog (open bars) and of the flux of filterable total $\mathrm{Hg}$ $\left(\mathrm{Hg}_{\mathrm{D}(\mathrm{flux})}\right)$ at the discharge end of the peat bog $(\boldsymbol{\square})$.

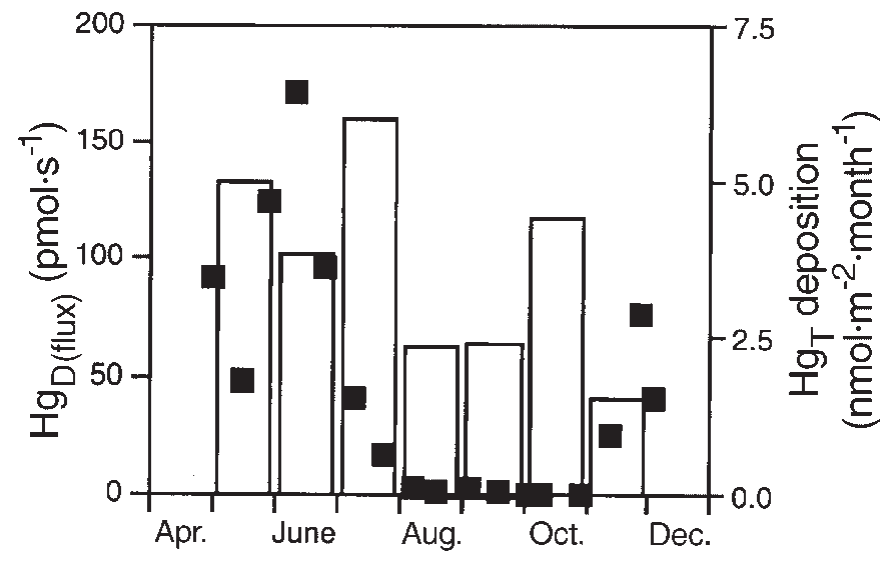

Fig. 4. The $\mathrm{MeHg}$ concentration in unfiltered peat water $\left(\mathrm{MeHg}_{\mathrm{T}}\right)$ versus the total $\mathrm{Hg}$ concentration in filtered $(0.45 \mu \mathrm{m})$ peat water $\left(\mathrm{Hg}_{\mathrm{D}}\right)$ at the discharge end of the peat bog. Each symbol represents one sample. Correlation coefficient $(r)=0.96$ $(P<0.0001)$. The significant probability $(P)$ was determined as if $\mathrm{MeHg}_{\mathrm{T}}$ and $\mathrm{Hg}_{\mathrm{D}}$ were independent variables. A least square fit regression line is also shown.

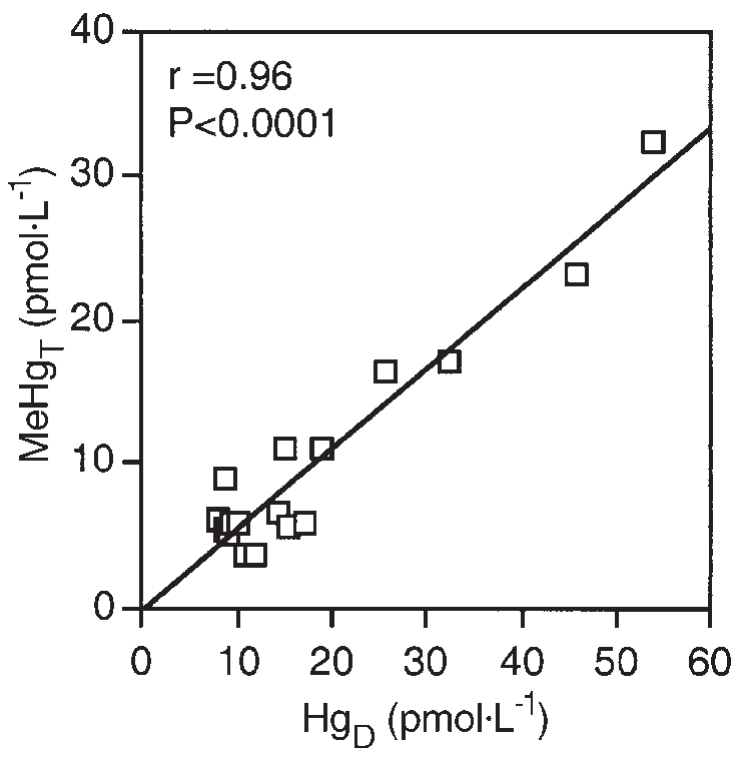

solid phase, it may be more appropriate to study $\left[\mathrm{MeHg}_{\mathrm{T}}\right]$ versus $\left[\mathrm{IHg}_{\mathrm{D}}\right]$ (e.g., Benoit et al. 2001). Indeed, this correlation was also highly significant (see below).

We did not measure the $\mathrm{Hg}$ levels in the solid matrix (peat and live moss). However, we believe that the particles $(<0.2 \mathrm{~mm}$ diameter) collected by the manually inserted cylinder consisted mostly of fragments, and possibly trapped particles, of the solid matrix. Dividing $\left[\mathrm{MeHg}_{\mathrm{P}}\right]$ by the concentration of suspended solids resulted in an average solidphase $\mathrm{MeHg}$ concentration of $42 \mathrm{ng} \cdot \mathrm{g}^{-1}$ dry weight (DW; range $\left.0-98 \mathrm{ng} \cdot \mathrm{g}^{-1} \mathrm{DW}\right)$, being close to the $53 \mathrm{ng} \cdot \mathrm{g}^{-1} \mathrm{DW}$ that Heyes et al. (2000) found in peat from a poor fen in Ontario. A similar calculation for $\mathrm{Hg}_{\mathrm{T}}$ suggests an average $\mathrm{Hg}_{\mathrm{T}}$ concentration of $410 \mathrm{ng} \cdot \mathrm{g}^{-1} \mathrm{DW}$ (range 87-1186 $\mathrm{ng} \cdot \mathrm{g}^{-1} \mathrm{DW}$ ),
Table 2. Correlation matrix with the variables indicated, based on measurements in the peat water at the discharge end of the peat bog $(n=17)$.

\begin{tabular}{llllll}
\hline & $\mathrm{Hg}_{\mathrm{D}}$ & $\mathrm{MeHg}_{\mathrm{T}}$ & Color & DOC & Sulfide \\
\hline $\mathrm{Hg}_{\mathrm{D}}$ & 1.00 & & & & \\
$\mathrm{MeHg}_{\mathrm{T}}$ & $0.96^{* * * *}$ & 1.00 & & & \\
Color & 0.43 & 0.51 & 1.00 & & \\
DOC & 0.21 & 0.23 & $0.72^{* *}$ & 1.00 & \\
Sulfide & 0.00 & 0.1 & $0.71^{* *}$ & $0.69 *$ & 1.00 \\
\hline
\end{tabular}

Note: $\mathrm{Hg}_{\mathrm{D}}$, filterable total $\mathrm{Hg}(0.45 \mu \mathrm{m})$; color, percent absorbance $(420 \mathrm{~nm})$ in water after filtration $(0.45 \mu \mathrm{m})$; DOC, dissolved organic carbon, i.e., organic carbon after filtration $(1.6 \mu \mathrm{m}) ; \mathrm{MeHg}_{\mathrm{T}}, \mathrm{MeHg}$ in bulk water; sulfide, sulfide in bulk water; *, $P<0.05$; **, $P<0.01$; ****, $P<$ 0.0001 (the significance test was treated as if the variables were independent (see the text).

being somewhat high in comparison with results from nearby peat bogs (mostly ombotrophic) in Sweden (200$300 \mathrm{ng} \cdot \mathrm{g}^{-1} \mathrm{DW}$ ) (Bindler et al. 2003). Notably, the concentrations of suspended solids and $\mathrm{Hg}$ were determined in separate water samples. Also, different filters were used to determine the concentrations of dissolved/particulate $\mathrm{Hg}$ and suspended solids $(0.45$ and $1.7 \mu \mathrm{m}$, respectively). This could explain any deviation from the true solid-phase $\mathrm{Hg}$ concentration.

Small-scale spatial variation of solid-phase $\mathrm{Hg}$ concentration probably contributed to the rather wide ranges reported above. Considering the probable fact that the particle concentration and composition varied and were affected by sampling, one may find it surprising that the relationship between $\left[\mathrm{MeHg}_{\mathrm{T}}\right]$ and $\left[\mathrm{Hg}_{\mathrm{D}}\right]$ was so strong. However, this relationship is partly explained by the fact that the variation of $\left[\mathrm{MeHg}_{\mathrm{T}}\right]$ depended almost entirely on the variation of $\left[\mathrm{MeHg}_{\mathrm{D}}\right]$ and was very little affected by the variation of $\left[\mathrm{MeHg}_{\mathrm{P}}\right]\left(\left[\mathrm{MeHg}_{\mathrm{P}}\right]=\left[\mathrm{MeHg}_{\mathrm{T}}\right]-\left[\mathrm{MeHg}_{\mathrm{D}}\right]\right)($ Fig. 6b). In contrast, the variation of $\left[\mathrm{IHg}_{\mathrm{T}}\right]$ was strongly correlated with $\left[\mathrm{IHg}_{\mathrm{P}}\right]$ and not with $\left[\mathrm{IHg}_{\mathrm{D}}\right]$ (Fig. $6 a$ ). Hence, $\left[\mathrm{IHg}_{\mathrm{T}}\right]$ did not appear to be significantly affected by the release of $\mathrm{IHg}$ from the solid phase, whereas $\left[\mathrm{MeHg}_{\mathrm{T}}\right]$ apparently was strongly affected by the release of $\mathrm{MeHg}$ from the solid phase, unless $\mathrm{MeHg}$ was produced in the liquid phase and stayed there. These relationships suggest that methylation either facilitated the release of $\mathrm{Hg}$ from the solid matrix or prevented its sorption to it. Here we assume that the degree of particle association (Fig. 6) can be used to predict the propensity of $\mathrm{MeHg}$ and $\mathrm{IHg}$ to be released from the solid matrix.

The average $\left[\mathrm{MeHg}_{\mathrm{D}}\right] /\left[\mathrm{IHg}_{\mathrm{D}}\right]$ ratio of 0.44 (range $0.09-$ 1.49) did not greatly differ from the average $\left[\mathrm{MeHg}_{\mathrm{P}}\right] /\left[\mathrm{IHg}_{\mathrm{P}}\right]$ ratio of 0.28 (range $0.00-1.21$ ). Hence, one could claim that $\mathrm{MeHg}$ and $\mathrm{IHg}$ showed similar partitioning behavior. However, this would be misleading considering the fact that a high porportion of $\mathrm{MeHg}$ was dissolved at high $\left[\mathrm{MeHg}_{\mathrm{T}}\right]$, whereas a high proportion of $\mathrm{IHg}$ was particulate at high $\left[\mathrm{IHg}_{\mathrm{T}}\right]$ (Fig. 6).

\section{Possible causes of the simultaneous buildup of $\left[\mathrm{MeHg}_{\mathrm{T}}\right]$ and $\left[\mathrm{Hg}_{\mathrm{D}}\right]$}

$\mathrm{MeHg}$ production (or $\mathrm{MeHg}$ release) is more related to $\mathrm{MeHg}_{\mathrm{T} \text { (flux) }}$ than to $\left[\mathrm{MeHg}_{\mathrm{T}}\right]$. Flux and concentration differ 
Fig. 5. Temporal variation of total $\mathrm{Hg}$ in filtered water $(0.45 \mu \mathrm{m})\left(\mathrm{Hg}_{\mathrm{D}}\right)$ and of $\mathrm{MeHg}$ in bulk water $\left(\mathrm{MeHg}_{\mathrm{T}}\right)$ at the discharge end of the peat bog, and the temporal variation of $\mathrm{MeHg}$ flux $\left(\mathrm{MeHg}_{\mathrm{T}(\mathrm{flux})}\right)$ from the peat bog and in the adjacent river. Each symbol represents one sample. (a) $\mathrm{MeHg}_{\mathrm{T}}(\boldsymbol{O})$ and $\mathrm{MeHg}_{\mathrm{D}}(\bigcirc)$. In two cases the solid and open symbols coincide. (b) $\mathrm{Hg}_{\mathrm{D}}$. $(c) \mathrm{MeHg}_{\mathrm{T}(\mathrm{flux})}(\mathbf{\Delta})$ and water discharge (-) from the peat bog. $(d) \operatorname{MeHg}_{\mathrm{T}(\text { flux })}(\mathbf{\Delta})$ and water discharge $(-)$ in the adjacent river.
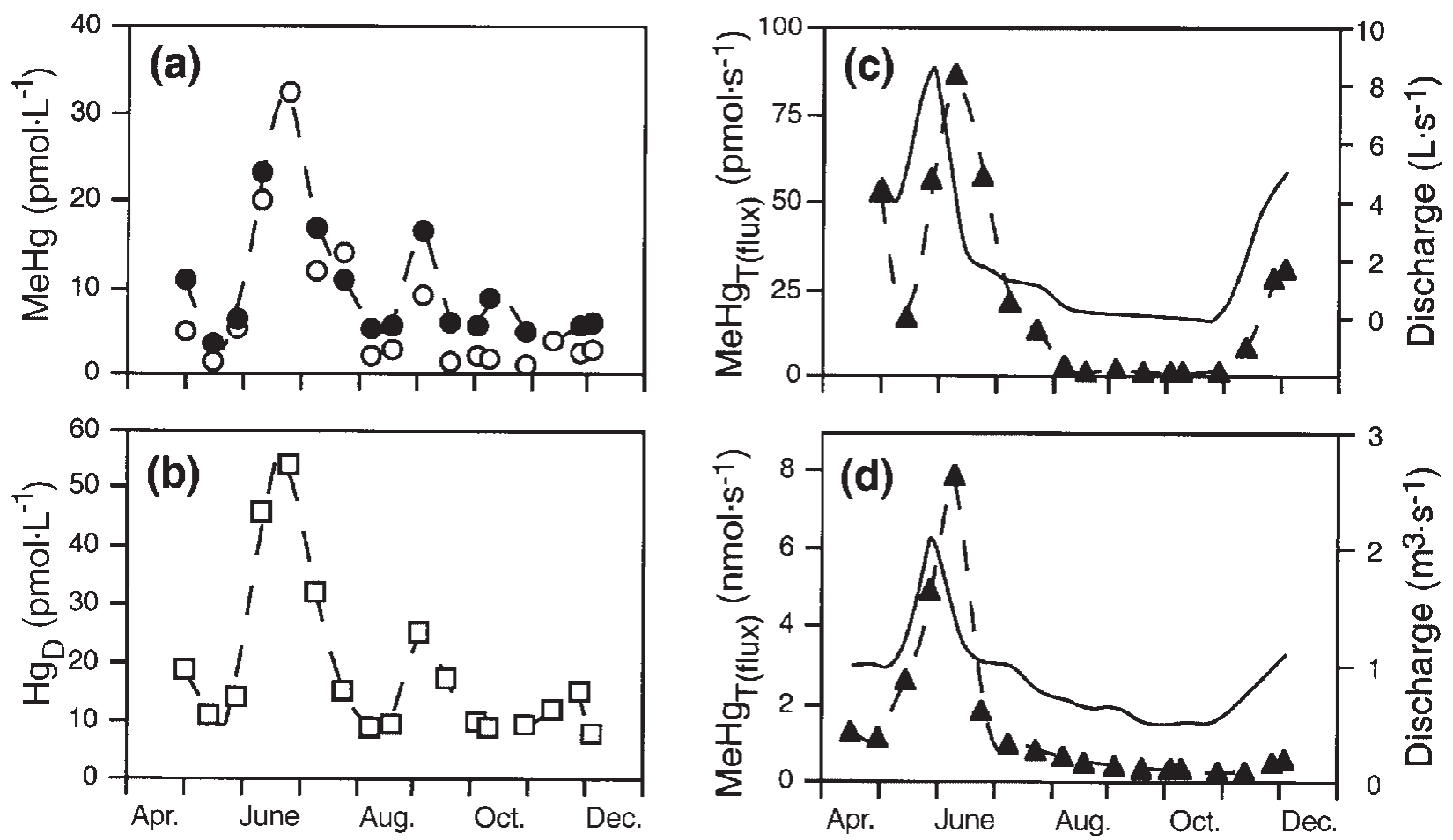

Fig. 6. Relationships between total, particulate ( $\square$ ), and dissolved ( $\square$ ) forms of $\mathrm{Hg}$. Each symbol represents one sample. (a) Inorganic $\mathrm{Hg}$ (IHg). The regression line is for $\mathrm{IHg}_{\mathrm{T}}$ versus $\mathrm{IHg}_{\mathrm{P}}(b) \mathrm{MeHg}$. The regression line is for $\mathrm{MeHg}_{\mathrm{T}}$ versus $\mathrm{MeHg}_{\mathrm{D}}$.

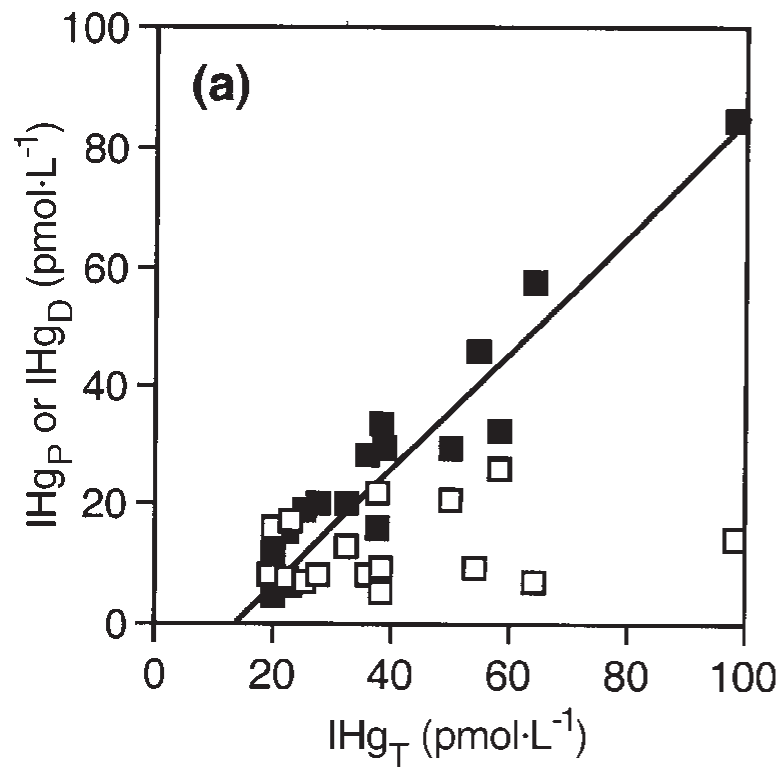

by a factor expressing water-flow rate $(Q)$. However, when different fluxes are compared, e.g., $\mathrm{MeHg}_{\mathrm{T} \text { (flux) }}$ and $\mathrm{Hg}_{\mathrm{D} \text { (flux), }}$, the term $Q$ is cancelled. Hence, it is sufficient to use concentration data when comparing fluxes.

One hypothesis is that the variation of $\mathrm{MeHg}_{\mathrm{T} \text { (flux) }}$ was due to partitioning, i.e., release from the solid phase to water, rather than to production of $\mathrm{MeHg}$. If so, the partitioning

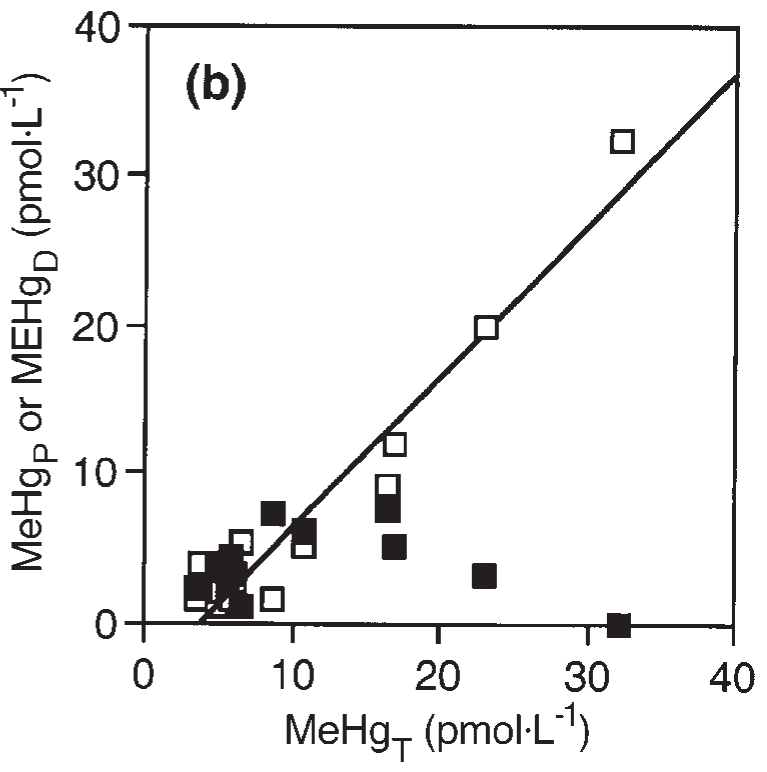

of $\mathrm{IHg}$ and $\mathrm{MeHg}$ between water and the solid phase must have responded similarly to changing conditions. Otherwise, the correlation between $\left[\mathrm{MeHg}_{\mathrm{T}}\right]$ and $\left[\mathrm{Hg}_{\mathrm{D}}\right]$ would be less strong (Fig. 4). Both $\mathrm{IHg}$ and $\mathrm{MeHg}$ could be released from solid OM during decomposition of OM by microorganisms. They could also be released during sulfide production, as free sulfide competes with functional groups on solid OM in 
Fig. 7. (a) Filterable total $\mathrm{Hg}\left(\mathrm{Hg}_{\mathrm{D}}\right)$ versus the color of filtered $(0.45 \mu \mathrm{m})$ peat water at the discharge end of the peat bog and $(b) \mathrm{Hg}$ versus sulfide in unfiltered peat water. Each symbol represents one sample.

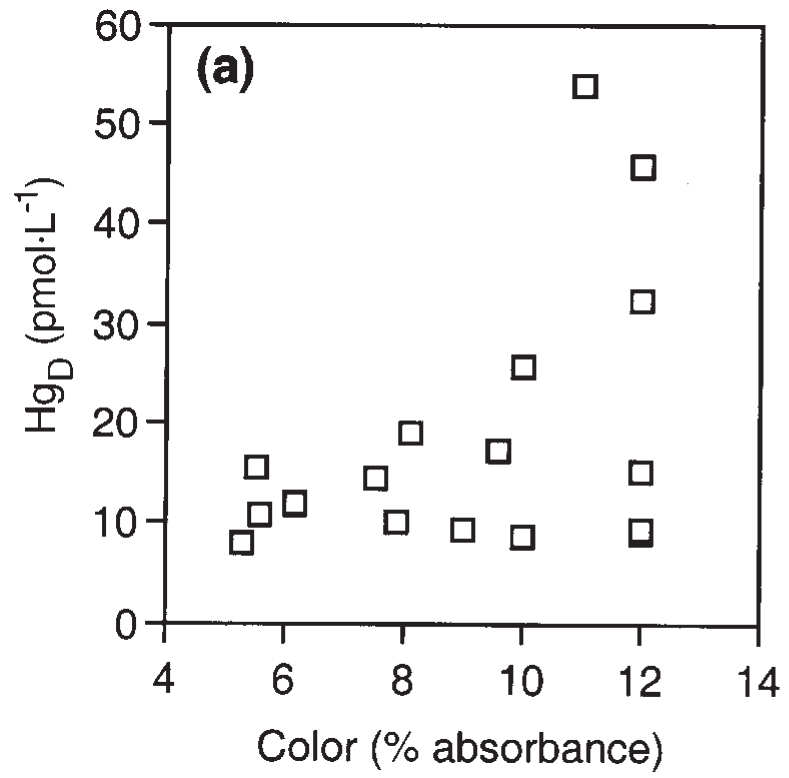

the binding of $\mathrm{MeHg}$ and $\mathrm{Hg}$ (II) (Hintelmann et al. 1997; Benoit et al. 1999; Drexel et al. 2002). Consequently, one would expect DOC and (or) sulfide to be positively correlated with $\left[\mathrm{Hg}_{\mathrm{D}}\right]$. However, neither DOC (color) nor sulfide showed a strong correlation with $\left[\mathrm{Hg}_{\mathrm{D}}\right]$ (Fig. 7, Table 2). The corresponding partial correlation coefficients (holding $\left[\mathrm{MeHg}_{\mathrm{T}}\right]$ constant) were also low: $r_{\text {color- } \mathrm{HgD}}=-0.26$ and $r_{\text {sulfide }-\mathrm{HgD}}=-0.31$. These are spurious, however, considering the fact that a significant fraction of $\mathrm{Hg}_{\mathrm{D}}$ is $\mathrm{MeHg}_{\mathrm{D}}$. More appropriate is to study color and sulfide versus $\left[\mathrm{IHg}_{\mathrm{D}}\right]$ when $\left[\mathrm{MeHg}_{\mathrm{T}}\right]$ is held constant. These partial correlation coefficients were low, too: $r_{\text {color-HgD }}=0.04$ and $r_{\text {sulfide- } \mathrm{HgD}}=-0.21$.

Moreover, $\mathrm{MeHg}_{\mathrm{T} \text { (flux) }}$ and $\mathrm{Hg}_{\mathrm{D} \text { (flux) }}$ peaked later than the water discharge (Fig. $5 c$ ). These observations suggest that a simple washout or change in partitioning did not explain the variation of $\mathrm{MeHg}_{\mathrm{T}(\text { flux })}$ and $\mathrm{Hg}_{\mathrm{D} \text { (flux) }}$. It cannot be ruled out, however, that $\mathrm{MeHg}$ and $\mathrm{IHg}$ might lag behind water, owing to exchange of $\mathrm{Hg}$ between the water and the porous sorbing media in the peat bog. Similarly, DOC and sulfide might not exhibit the same retardation as $\mathrm{Hg}$. This could explain why $\mathrm{MeHg}_{\mathrm{T}}, \mathrm{Hg}_{\mathrm{D}}$, and $\mathrm{IHg}_{\mathrm{D}}$ were poorly correlated with both sulfide and DOC. Furthermore, vertical chemical gradients within the sampled layers could obscure such relationships. Heyes et al. (2000) found that the $\mathrm{MeHg}$ concentration in peat pore water from a poor fen in Ontario was highest in the upper layers of the profile, well above the lowest depth $(90 \mathrm{~cm})$ sampled in the present study. However, one would expect sulfate reduction and DOC production to coincide with $\mathrm{Hg}$ methylation.

Alternatively, the variation of $\mathrm{MeHg}_{\mathrm{T}(\text { flux })}$ was entirely a result of variation of $\mathrm{Hg}$ methylation. In view of the fact that the stability of $\mathrm{MeHg}$ might be lower than has previously been assumed (Hintelmann et al. 2000), it seems likely that $\mathrm{MeHg}$ levels in most environments are highly dependent on fresh production of $\mathrm{MeHg}$. If $\mathrm{Hg}$ methylation takes place in the cytoplasm of dissimilatory sulfate-reducing bacteria, as is currently assumed, only dissolved $\mathrm{Hg}$ complexes should

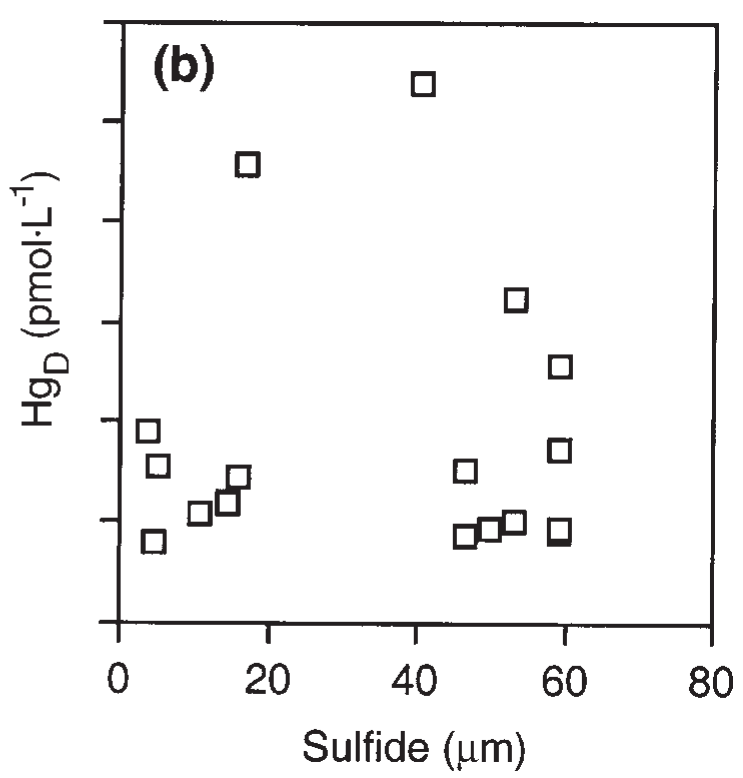

be available for methylation. Cells probably do not scavenge $\mathrm{Hg}$ directly from solids to a significant extent, given the fact that virtually all particulate $\mathrm{Hg}$ (II) is either bound in solid sulfides or strongly bound to OM via thiol groups (Schlüter 1996; Wallschläger et al. 1996; Hesterberg et al. 2001). Hence, the strong correlation between $\left[\mathrm{MeHg}_{\mathrm{T}}\right]$ and $\left[\mathrm{Hg}_{\mathrm{D}}\right]$ could be explained by cellular uptake of $\mathrm{IHg}_{\mathrm{D}}$ followed by intracellular methylation of $\mathrm{IHg}$. Notably, both $\left[\mathrm{MeHg}_{\mathrm{T}}\right]$ and $\left[\mathrm{Hg}_{\mathrm{D}}\right]$ showed a strong correlation with $\left[\mathrm{IHg}_{\mathrm{D}}\right](r=0.84$ and $r=0.93$, respectively).

Evidently, intracellular methylation could explain the strong relationship between $\left[\mathrm{MeHg}_{\mathrm{T}}\right]$ and $\left[\mathrm{Hg}_{\mathrm{D}}\right]$, but could it also account for the $\left[\mathrm{MeHg}_{\mathrm{T}}\right] /\left[\mathrm{IHg}_{\mathrm{D}}\right]$ ratio of 0.79 (range $0.37-1.49)$ ? In natural waters, any $\mathrm{Hg}(\mathrm{II})$ that passes $0.45 \mu \mathrm{m}$ filters is either complexed by various organic compounds, most of which are of a colloidal nature and too large to pass cell membranes (Stordal et al. 1996; Wallschläger et al. 1998), or is complexed by sulfide (Benoit et al. 1999). Also note that the ability of $\mathrm{IHg}_{\mathrm{D}}$ to pass cell membranes would have to be greater than indicated by the $\left[\mathrm{MeHg}_{\mathrm{T}}\right] /$ $\left[\mathrm{IHg}_{\mathrm{D}}\right]$ ratios if not all of the $\mathrm{IHg}$ entering the cells was converted to $\mathrm{MeHg}$, or if some of the $\mathrm{MeHg}$ produced was demethylated. It does not seem likely that all cells absorbing $\mathrm{IHg}$ were vigorous $\mathrm{Hg}$ methylators and that demethylation was negligible. St. Louis et al. (2004) concluded that demethylation had a strong effect on $\mathrm{MeHg}$ levels in the wetland system they studied in northwestern Ontario.

The $\left[\mathrm{MeHg}_{\mathrm{T}}\right] /\left(\left[\mathrm{IHg}_{\mathrm{D}}\right]+\left[\mathrm{MeHg}_{\mathrm{T}}\right]\right)$ ratio is a more conservative measure of the availability of $\mathrm{Hg}$ for methylation. It takes into account that $[\mathrm{MeHg}]$ might build up, while $\left[\mathrm{IHg}_{\mathrm{D}}\right]$ is consumed. This ratio averaged 0.46 (range $0.27-0.93$ ). It is still high enough to raise the question whether intracellular methylation of $\mathrm{Hg}$ released from the solid phase could explain the observed $\mathrm{MeHg}$ levels.

As already stated, $\mathrm{Hg}(\mathrm{II})$ is strongly bound to organic matter via reduced sulfur groups. It seems likely that virtually all $\mathrm{Hg}$ entering the peat bog is rapidly sorbed by live 
Fig. 8. Water level (-), water temperature (- -), and the flux of $\mathrm{MeHg}\left(\mathrm{MeHg}_{\mathrm{T}(\mathrm{flux})}\right.$; $\left.\mathbf{\square}\right)$. For clarity, the scale of $\mathrm{MeHg}_{\mathrm{T}(\mathrm{flux})}$ is omitted (it is shown in Fig. 4). (a) In the river. (b) In the peat bog. The water level shown for the peat bog was gauged at the observation well closest to the peat water sampling site. The peat surface at the observation well was at $147.79 \mathrm{~m}$.

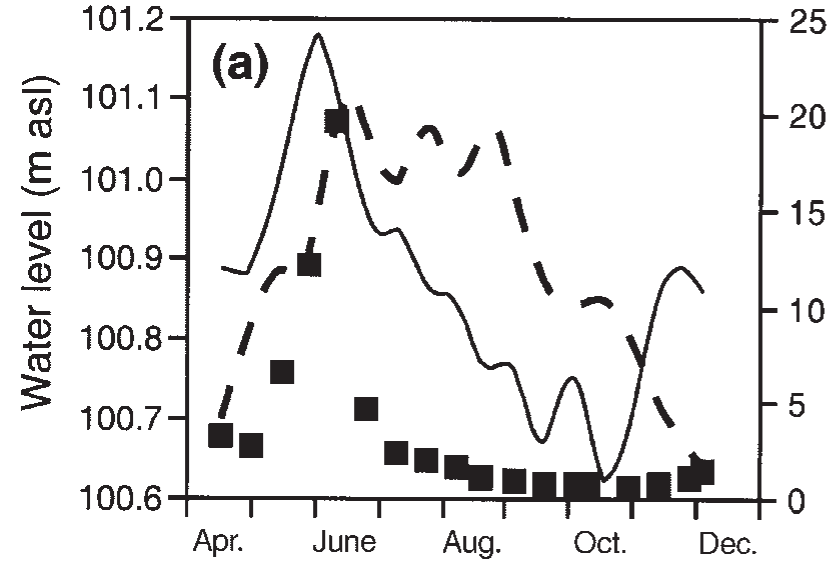

moss and peat (including attached microorganisms), and by free-living cells. An interesting possibility is that the sorbed $\mathrm{Hg}$ is released back to the peat water mainly as a result of a weakening of $\mathrm{Hg}-\mathrm{S}$ bonds by methylation of $\mathrm{Hg}$. Furthermore, $\mathrm{Hg}$ passes cell membranes much more rapidly when methylated (Carty and Malone 1979; Mason et al. 1996). Hence, methylation should increase cellular release of $\mathrm{Hg}$. The cause-effect relationship between $\left[\mathrm{MeHg}_{\mathrm{T}}\right]$ and $\left[\mathrm{Hg}_{\mathrm{D}}\right]$ would then be that methylation causes release of $\mathrm{Hg}$, not vice versa.

A similar possibility in line with a high $[\mathrm{MeHg}] /\left[\mathrm{IHg}_{\mathrm{D}}\right]$ ratio is that any $\mathrm{IHg}$ released from the solid phase is immediately sorbed by microorganisms (Benoit et al. 2001) and that $\mathrm{Hg}$ stays bound to the microbial cells as long as no methylation occurs. In that case, methylation does not cause the initial release of $\mathrm{Hg}$ from the solid phase, but causes a secondary release of resorbed $\mathrm{Hg}$.

Notably, methylation being the main cause of $\mathrm{Hg}$ release would help to explain the fact that sulfide and DOM levels were poorly correlated with $\left[\mathrm{Hg}_{\mathrm{D}}\right]$ (Table 2 ). Also note that if $\mathrm{Hg}$ methylation in the cytoplasm of bacteria is the main cause of $\mathrm{Hg}$ release, this would imply that most of the $\mathrm{Hg}$ which is released from the solid phase has passed a bacterial cell membrane twice. No effort has been made so far to specifically show that $\mathrm{Hg}$ methylation does take place mainly in the cytoplasm of bacteria. We would therefore not rule out the possibility that $\mathrm{Hg}$ methylation is at least partly a surface-mediated reaction occurring on cell surfaces, from which $\mathrm{MeHg}$ is released as $\mathrm{MeHgSH}$ in the presence of free sulfide.

\section{Demethylation inferred?}

If methylation was indeed the main cause of $\mathrm{Hg}$ release to the water, and if $\left[\mathrm{Hg}_{\mathrm{D}}\right]$ was largely explained by $\mathrm{Hg}$ release from the solid phase, it would follow that most of the $\mathrm{Hg}_{\mathrm{D}}$ that was not present as $\mathrm{MeHg}$ was formed secondarily from $\mathrm{MeHg}$.

$\mathrm{MeHg}$ can be degraded by microorganisms (Oremland et al. 1991; Pak and Bartha 1998), photodegraded (Sellers et al. 1996), and consumed in chemical reactions involving sulfide (Craig and Moreton 1984; Baldi et al. 1993; Wallschläger et al. 1995). $\mathrm{Hg}$ (II) resulting from demethylation of $\mathrm{MeHg}$ could

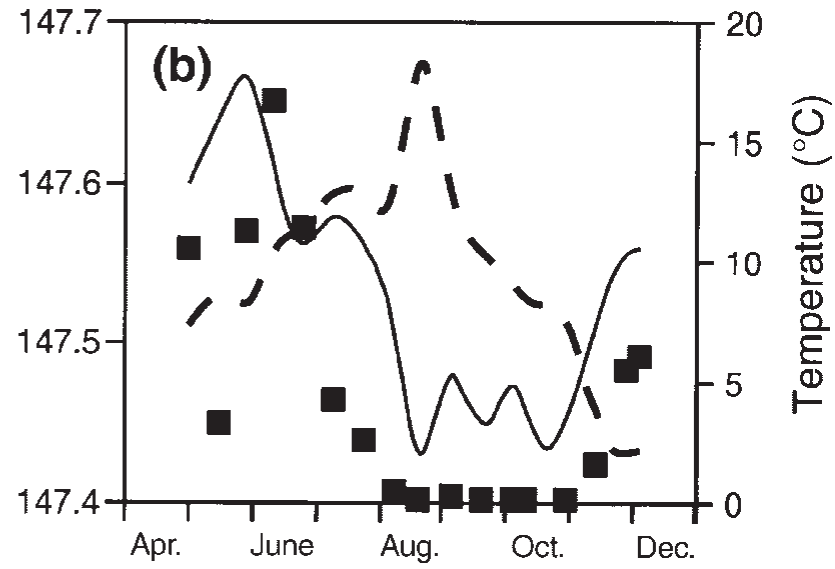

be kept in solution or in a colloidal state by polysulfides and OM (e.g., Paquette and Helz 1997; Ravichandran et al. 1999), or simply stay in solution as $\mathrm{HgS}$ or $\mathrm{Hg}(\mathrm{SH})_{2}$ (Benoit et al. 1999).

However, if methylation and release of $\mathrm{IHg}$ occurred simultaneously, demethylation does not have to be inferred to explain the fact that the average $\left[\mathrm{MeHg}_{\mathrm{D}}\right] /\left[\mathrm{Hg}_{\mathrm{D}}\right]$ ratio did not exceed 0.28 (range $0.08-0.60$ ). The production of strong complexing agents is likely to coincide with $\mathrm{MeHg}$ production. (Sulfate-reducing bacteria could be responsible for both $\mathrm{Hg}$ methylation and production of sulfide.) Strong complexing agents might also extract $\mathrm{Hg}$ (II) from the solid phase. As noted above, the fact that DOC and sulfide levels did not show a strong correlation with $\left[\mathrm{MeHg}_{\mathrm{T}}\right]$ and $\left[\mathrm{Hg}_{\mathrm{D}}\right]$ (Fig. 7, Table 2) does not exclude the possibility that release of $\mathrm{Hg}$ from the solid phase was at least partly a direct result of decomposition of $\mathrm{OM}$ and formation of $\mathrm{Hg}(\mathrm{II})$-sulfide complexes.

The rather wide range of $\left[\mathrm{MeHg}_{\mathrm{D}}\right] /\left[\mathrm{IHg}_{\mathrm{D}}\right]$ ratios $(0.09-$ 1.49 ) is worth noting. The low values within this range seem to argue against the view that methylation had a strong influence on $\left[\mathrm{Hg}_{\mathrm{D}}\right]$. However, note that the low values represent time periods of low $\left[\mathrm{Hg}_{\mathrm{D}}\right]$ (Figs. $5 a, 5 b$ ). Low $\left[\mathrm{MeHg}_{\mathrm{D}}\right] /$ $\left[\mathrm{IHg}_{\mathrm{D}}\right]$ ratios could be the net result of low methylation rates, high demethylation rates, and a higher uptake of $\mathrm{MeHg}$ than of $\mathrm{Hg}$ (II) by cells. Low methylation rates can be expected to coincide with high specific cellular uptake of $\mathrm{MeHg}$, since production of both $\mathrm{MeHg}$ and reduced sulfur ligands (which will compete with cells for $\mathrm{MeHg}$ ) can be expected to decrease as a result of lowered anaerobic microbial activity.

\section{Temporal variation of $\mathrm{MeHg}$ in the peat water and in the river}

The temporal variation of $\mathrm{MeHg}_{\mathrm{T} \text { (flux) }}$ in the peat bog was strikingly similar to that in the river passing through the adjacent lake (Figs. $5 c, 5 d$ ). Any of the five river stations, some of which were situated upstream of the study peat bog, could have been chosen to show this (data are shown for one station only). Hence, $\mathrm{Hg}$ methylation and (or) release of $\mathrm{MeHg}$ to the water appeared to be controlled by the same processes along the river as in the study peat bog. Notably, 
in both the river and the peat bog, the maximum water discharge preceded the maximum $\mathrm{MeHg}_{\mathrm{T}(\text { flux })}$. We believe that a high water table in combination with a rise in temperature favored anaerobic microbial activity that, in turn, caused both increased $\mathrm{Hg}$ methylation and increased release of $\mathrm{MeHg}$ from the solid phase (Fig. 8). Possibly, $\mathrm{MeHg}_{\mathrm{T}(\mathrm{flux})}$ lagged behind the water discharge because it takes some time for anaerobic conditions to develop.

\section{Dynamics of $\mathrm{Hg}$ in minerotrophic peat bogs}

Large amounts of live and dead OM should lead to a high retention of $\mathrm{Hg}$ in wetlands. However, the retention of $\mathrm{Hg}$ in wetlands is often lower than in drier upland soils. Hence, there must be processes in wetlands that cause removal of $\mathrm{Hg}$ from solid OM. Such processes could be mineralization of OM, extraction of $\mathrm{Hg}$ (II) bound to OM by reduced sulfur compounds, and $\mathrm{Hg}$ methylation. In the peat bog we studied, it was clear that $\mathrm{MeHg}$ was more mobile than $\mathrm{Hg}$ (II). This is possibly explained by the fact that $\mathrm{Hg}$ (II) has a higher affinity than $\mathrm{MeHg}$ for reduced sulfur groups on OM, and hence is more difficult to remove from such binding sites. We found evidence that methylation, rather than sulfide complexation of $\mathrm{Hg}$ (II) and $\mathrm{OM}$ mineralization, was controlling the release of $\mathrm{Hg}$. Firstly, $\left[\mathrm{MeHg}_{\mathrm{T}}\right]$ was strongly correlated with $\left[\mathrm{Hg}_{\mathrm{D}}\right]$, whereas sulfide and DOC levels were not. Secondly, $\mathrm{MeHg}_{\mathrm{D}}$ comprised a large part of $\mathrm{Hg}_{\mathrm{D}}$, especially when $\left[\mathrm{Hg}_{\mathrm{D}}\right]$ was high (Figs. $5 a, 5 b$ ).

We believe that the dynamics of $\mathrm{Hg}$ in the studied peat bog were characterized by rapid sorption of $\mathrm{Hg}$ entering the peat bog with upland runoff water and precipitation, followed by release of $\mathrm{Hg}$ to the water, mainly as a result of methylation of $\mathrm{Hg}$ (II) in combination with a high concentration of strong complexing agent in the water. Yet we cannot exclude the possibility that significant quantities of $\mathrm{Hg}$ were also released as $\mathrm{IHg}$.

\section{Acknowledgements}

The study was supported by the Swedish Environmental Protection Agency. A. Helgée and B. Troedsson helped in the planning and execution of the fieldwork. Dr. P. Elander was in charge of the hydrological investigation. The mercury analyses were carried out at the Swedish Environmental Research Institute, Gothenburg. Mr. K.F.K. Larsson provided linguistic advice. Dr. P. Larsson, Dr. Wen-Qi Wu, Dr. O. Wendt, Dr. B. Wallén, Dr. O. Berglund, and Dr. B. Ekberg provided useful comments.

\section{References}

Baldi, F., Pepi, M., and Filipelli, M. 1993. Methylmercury resistance in Desulfovibrio desulfuricans strains in relation to methylmercury degradation. Appl. Environ. Microbiol. 59: 2479-2485.

Benoit, J.M., Gilmour, C.C., Mason, R.P., and Heyes, A. 1999. Sulfide controls on mercury speciation and bioavailability to methylating bacteria in sediment porewaters. Environ. Sci. Technol. 33: 951-957.

Benoit, J.M., Gilmour, C.C., and Mason, R.P. 2001. The influence of sulfide on solid-phase mercury bioavailability for methylation by pure cultures of Desulfobulbus propionicus (1pr3). Environ. Sci. Technol. 35: 127-132.
Bindler, R. 2003. Estimating the natural background atmospheric deposition rate of mercury utilizing ombotrophic bogs in southern Sweden. Environ. Sci. Technol. 37: 40-46.

Branfireun, B.A., Heyes, A., and Roulet, N.T. 1996. The hydrology and methylmercury dynamics of a Precambrian shield headwater peatland. Water Resour. Res. 32: 1785-1794.

Branfireun, B.A., Roulet, N.T., Kelly C.A., and Rudd, J.W.M. 1999. In situ sulphate stimulation of mercury methylation in a boreal peatland: toward a link between acid rain and methylmercury contamination in remote environments. Global Biogeochem. Cycles, 13: $743-750$.

Carty, A.J., and Malone, S.F. 1979. The chemistry of mercury in biological systems. In The biogeochemistry of mercury in the environment. Edited by J.O. Nriagu. Elsevier/North-Holland Biomedical Press, New York. pp. 433-479.

Choi, B.H. 1991. Effects of methylmercury on the developing brain. In Advances in mercury toxicology. Edited by T. Suzuki, N. Imura, and T. Clarkson. Plenum Press, New York. pp. 315-333.

Clarkson, T.W. 1990. Human health risks from methylmercury in fish. Environ. Toxicol. Chem. 9: 957-961.

Compeau, G.C., and Bartha, R. 1984. Methylation and demethylation of mercury under controlled redox, $\mathrm{pH}$, and salinity conditions. Appl. Environ. Microbiol. 48: 1203-1207.

Compeau, G.C., and Bartha, R. 1985. Sulfate-reducing bacteria: principal methylators of mercury in anoxic estuarine sediment. Appl. Environ. Microbiol. 50: 498-502.

Craig, P.J. 1986. Occurrence and pathways of organometallic compounds in the environment - general considerations. In Organometallic compounds in the environment: principles and reactions. Edited by P.J. Craig. Longman Group Ltd., Harlow, England. pp. 1-64.

Craig, P.J., and Moreton, P.A. 1984. The role of sulphide in the formation of dimethyl mercury in river and estuary sediments. Mar. Pollut. Bull. 15: 406-408.

Drexel, R.T., Haitzer, M., Ryan, J.N., Aiken, G.R., and Nagy, K.L. 2002. Mercury (II) sorption to two Florida Everglades peats: evidence for strong and weak binding and competition by dissolved organic matter released from peat. Environ. Sci. Technol. 36: 4058-4064.

Driscoll, C.T., Schofield, C.L., Munson, R., and Holsapple, J. 1994. The mercury cycle and fish in the Adirondack lakes. Environ. Sci. Technol. 28: 136A-143A.

Fonselius, S.H. 1983. Determination of hydrogen sulfide. In Methods of sea water analysis. Edited by K. Grasshoff, M. Erhardt, and K. Kremling. Verlag Chemie, Weinheim, Germany, and Deerfield Beach, Fla. pp. 73-80.

Gilmour, C.C., Henry, E.A., and Mitchell, R. 1992. Sulfate stimulation of mercury methylation in freshwater sediment. Environ. Sci. Technol. 26: 2281-2287.

Hesterberg, D., Chou, J.F., Hutchison, K.J., and Sayers, D.E. 2001. Bonding of $\mathrm{Hg}$ (II) to reduced organic sulfur in humic acid as affected by S/Hg ratio. Environ. Sci. Technol. 35: 2741-2745.

Heyes, A, Moore, T.R., Rudd, J.W.M, and Dugoua, J.J. 2000. Methyl mercury in pristine and impounded peatlands, Experimental Lakes Area, Ontario. Can. J. Fish. Aquat. Sci. 57: 2211-2222.

Hintelmann, H., Welbourn, P.M., and Evans, R.D. 1997. Measurement of complexation of methylmercury(II) compounds by freshwater humic substances using equilibrium dialysis. Environ. Sci. Technol. 31: 489-495.

Hintelmann, H., Keppel-Jones, K., and Evans, R.D. 2000. Constants of mercury methylation and demethylation rates in sediments and comparison of tracer and ambient mercury availability. Environ. Toxicol. Chem. 19: 2204-2211. 
Hurley, J.P., Benoit, J.M., Babiarz, C.L., Shafer, M.M., Andren, A.W., Sullivan, J.R. et al. 1995. Influences of watershed characteristics on mercury levels in Wisconsin rivers. Environ. Sci. Technol. 29: 1867-1875.

Iverfeldt, A. 1991. Occurrence and turnover of atmospheric mercury over the Nordic countries. Water Air Soil Pollut. 56: 251-265.

Jackson, T.A. 1998. Mercury in aquatic ecosystems. In Metal metabolism in aquatic environments. Edited by W.J. Langston and M.J. Bebianno. Chapman \& Hall, London. pp. 77-138.

Johansson, K., Bergbäck, B., and Tyler, G. 2001. Impact of atmospheric long-range transport of lead, mercury and cadmium on the Swedish forest environment. Water Air Soil Pollut. Focus, 1: 279-297.

Mason, R.P., Reinfelder, J.R., and Morel, F.M.M. 1996. Uptake, toxicity, and trophic transfer of mercury in a coastal diatom. Environ. Sci. Technol. 30: 1835-1845.

Mierle, G. 1990. Aqueous inputs of mercury to Precambrian Shield lakes in Ontario. Environ. Toxicol. Chem. 9: 843-851.

Mierle, G, and Ingram, R. 1991. The role of humic substances in the mobilization of mercury from watersheds. Water Air Soil Pollut. 56: 349-357.

Oremland, R.S., Culberstson, C.W., and Winfrey, M.R. 1991. Methylmercury decomposition in sediments and bacterial cultures: involvement of methanogens and sulfate reducers in oxidative demethylation. Appl. Environ. Microbiol. 57: 130-137.

Pak, K.-R., and Bartha, R. 1998. Mercury methylation and demethylation in anoxic lake sediments by strictly anaerobic bacteria. Appl. Environ. Microbiol. 64: 1013-1017.

Paquette, K.E., and Helz, G.R. 1997. Inorganic speciation of mercury in sulfidic waters: the importance of zero-valent sulfur. Environ. Sci. Technol. 31: 2148-2153.

Quemarais, B., Cossa, D., Rondeau, B., Pham, T.T., Gagnon, P., and Fortin, B. 1999. Sources and fluxes of mercury in the St. Lawrence River. Environ. Sci. Technol. 33: 840-849.

Ravichandran, M., Aiken, G.A., Ryan, N.Y., and Reddy, M.M. 1999. Inhibition of precipitation and aggregation of metacinnabar (mercuric sulfide) by dissolved organic matter isolated from the Florida Everglades. Environ. Sci. Technol. 33: 1418-1423.

Regnell, O., and Tunlid, A. 1991. Laboratory study of chemical speciation of mercury in lake sediment and water under aerobic and anaerobic conditions. Appl. Environ. Microbiol. 57: 789-795.

Regnell, O., Ewald, G., and Lord, E. 1997. Factors controlling temporal variation in methyl mercury levels in a seasonally stratified lake. Limnol. Oceanogr. 42: 1784-1795.

Regnell, O., Hammar, T., Helgée, A., and Troedsson, B. 2001. Effects of anoxia and sulfide on concentrations of total and methyl mercury in sediment and water in two $\mathrm{Hg}$-polluted lakes. Can. J. Fish. Aquat. Sci. 58: 506-517.
Schlüter, K. 1996. Translocation of ${ }^{203} \mathrm{Hg}$ labelled $\mathrm{HgCl}_{2}$ and $\mathrm{CH}_{3} \mathrm{HgCl}$ in an iron-humus podzol studied by radio-analytical techniques. Z. Pflanzenernaehr. Bodenkd. 159: 215-226.

Sellers, P., Kelly, C.A., Rudd, J.W.M., and MacHutchon, A.R. 1996. Photodegradation of methylmercury in lakes. Nature (Lond.), 380: 694-697.

Sokal, R.R., and Rohlf, F.J. 1995. Biometry. 3rd ed. W.H. Freeman and Co., New York.

Sorensen, J.A., Glass, G.E., Schmidt, K.W., Huber, J.K., and Rapp, G.R., Jr. 1990. Airborne mercury deposition and watershed characteristics in relation to mercury coencentrations in water, sediments, plankton, and fish of eighty northern Minnesota lakes. Environ. Sci. Technol. 24: 1716-1727.

St. Louis, V.L., Rudd, J.W.M., Kelly, C.A., Beaty, K.G., Bloom, N.S., and Flett, R.J. 1994. Importance of wetlands as sources of methyl mercury to boreal forest ecosystems. Can. J. Fish. Aquat. Sci. 51: 1065-1076.

St. Louis, V.L., Rudd, J.W.M., Kelly, C.A., Bodaly, R.A. (Drew), Paterson, M.J., Beaty, K.G., Hesslein, R.H., Heyes, A., and Majewski, A.R. 2004. The rise and fall of mercury methylation in an experimental reservoir. Environ. Sci. Technol. 38: 1348-1358.

Stordal, M.C., Gill, G.A., Wen, L.-S., and Santschi, P.H. 1996. Mercury speciation in the surface waters of three Texas estuaries: importance of colloidal forms. Limnol. Oceanogr. 41: 52-61.

Surma-Aho, K., Paasivirta, J., Rekolainen, S., and Verta, M. 1986. Organic and inorganic mercury in the food chain of some lakes and reservoirs in Finland. Chemosphere, 15: 353-372.

Swain, E.B., Engstrom, D.R., Brigham, M.E., Henning, T.A., and Brezonik, P.L. 1992. Increasing rates of atmospheric deposition in midcontinental North America. Science (Wash., D.C.), 257: 784-787.

Waldron, M.C., Colman, J.A., and Breault, R.F. 2000. Distribution, hydrologic ransport, and cycling of total mercury and methyl mercury in a contaminated river-reservoir-wetland system (Sudbury River, eastern Massachusetts). Can. J. Fish. Aquat. Sci. 57: 1080-1091.

Wallschläger, D., Hintlmann H., Evans, R.D., and Wilken., R.-D. 1995. Volatilization of dimethylmercury and elemental mercury from River Elbe floodplain soils. Water Air Soil Pollut. 80: $1325-1329$.

Wallschläger, D., Desai, M.V.M., Spengler, M., and Wilken, R.-D. 1996. The role of humic substances in the aqueous mobilization of mercury from contaminated floodplain soils. Water Air Soil Pollut. 90: 507-520.

Wallschläger, D., Desai, M.V.M., Spengler, M., Windmöller, C.C., and Wilken, R.-D. 1998. How humic substances dominate mercury geochemistry in contaminated floodplain soils and sediments. J. Environ. Qual. 27: 1044-1054. 